\title{
EDUCATIONAL OPTIONS IN TEACHING TECHNICAL SUBJECTS BY MEANS OF VIRTUAL MEASUREMENT SYSTEMS AND INTERNET
}

\author{
Miroslav GUTTEN - Daniel KORENČIAK
}

\begin{abstract}
Lab measuring lecture through internet is one of the progressive educational methods, having a potential to be applied for any science or technical subject, e.g. physics, electrotechnics, measuring etc. It is inevitable to understand that such measuring lectures are supplementary tool for improvement of regular lectures. Lab measuring lectures over the internet are intended to make the subject more attractive as well as to unburden teacher's schedule.
\end{abstract}

Key words: internet, device, virtual, measuring system, measurement, LabVIEW

\section{MOŽNOSTI VÝUČBY TECHNICKÝCH PREDMETOV POMOCOU VIRTUÁLNYCH MERACÍCH SYSTÉMOV A INTERNETU}

\begin{abstract}
Abstrakt: Laboratórne meranie cez internet je jedným z progresívnych vyučovaní, ktoré je možné zaviest' na každom prírodovednom či technickom predmete, ako je napr. fyzika, elektrotechnika, meranie apod. Je však potrebné, aby takéto merania boli len doplňujúcim prostriedkom pre zlepšenie výučby riadneho vyučovania. Laboratórne merania cez internet majú vyučovaný predmet zatraktívnit' a pokial' možno znižit' prípadný vel'ký úväzok vyučujúceho.
\end{abstract}

Kl'účové slová: internet, prístroj, virtuálny, merací systém, meranie, LabVIEW

1. Introduction to on-line measurement at universities

System model for on-line measuring of electrical and non-electrical parameters in laboratory conditions is nowadays gaining more interest in relation to application of interactive educational methods at Slovak universities.

Most of the universities intend to provide students with maximum studying possibilities and implement interactive lectures and practical lessons from theoretical as well as practical technical subjects.

Nowadays there is a possibility to choose such a measuring system which would enable a student to carry out measurement task from science or electrotechnical subject from home, student house or university premises. In order to achieve desired educational purpose of these practical measuring lessons, they necessarily need to follow practical lessons schedule and at least $50 \%$ of practical lessons should a student carry out directly in a laboratory. By application of different educational techniques, students gain additional experience in using new modern measuring methods. This method of measuring the parameters originates in a principle that there is a opportunity to digitalize the physical model, transfer it over the internet and observe and measure parameters related to circuit of specific physical model or to electric and electronic circuit through PC monitor. Described measuring method contributes to higher added value to the student, especially concerning content and quality of education. Utilizing the virtual practical lessons, the student is enabled to make multiple verification of his theoretical knowledge and has an opportunity to apply this knowledge in practical life.

\section{Significance of virtual measuring systems}

Measuring systems and data collection systems based on up-to-date technical and programming devices are very student-friendly, if used for measuring over internet.

Enormous performance of computers and software are fully utilized. Based on this situation, the user's computer needs to acquire interfaces with physical environment and the computer basically changes to virtual measuring system or monitoring desk which is capable of carrying out on-line measurements over internet.

Producers provide wide range of devices and programming environments which ease the design and implementation of virtual measuring system. The main criterion is to help the user create a mutually compatible system. 
Virtual measuring instrument (VI) is an instrument whose general function and abilities are mainly defined by software. In other words, virtual instrument is the instrument that actually „does not exist“".

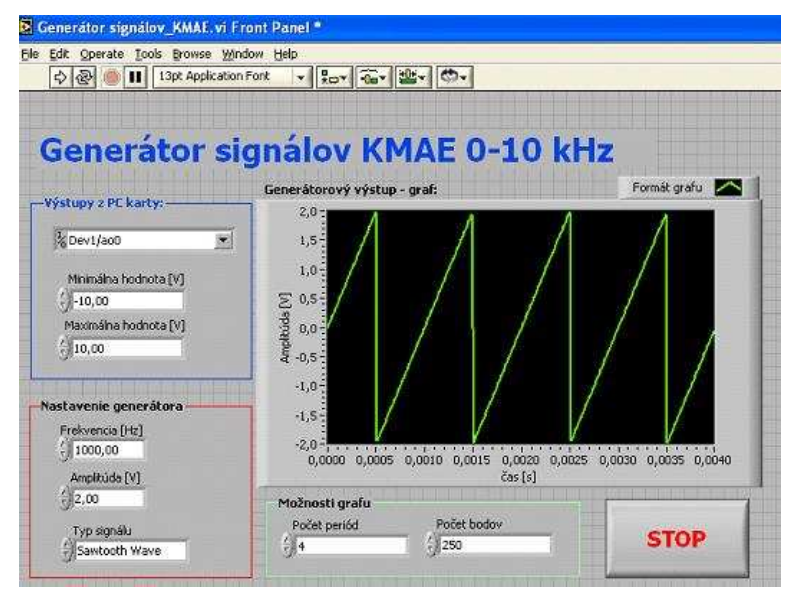

Fig.1: Main panel of VI generator

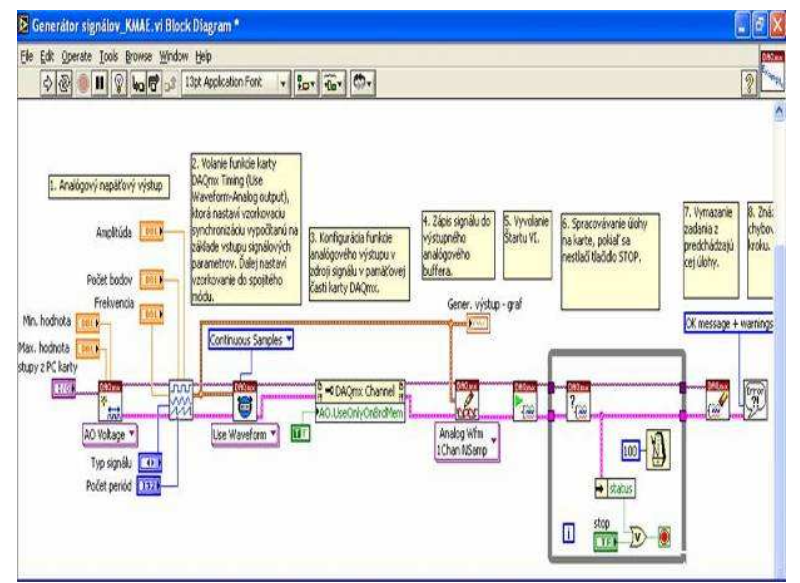

Fig. 2: Flow chart of VI generator (created at Department of Measurement and Applied Electrical in Žilina)

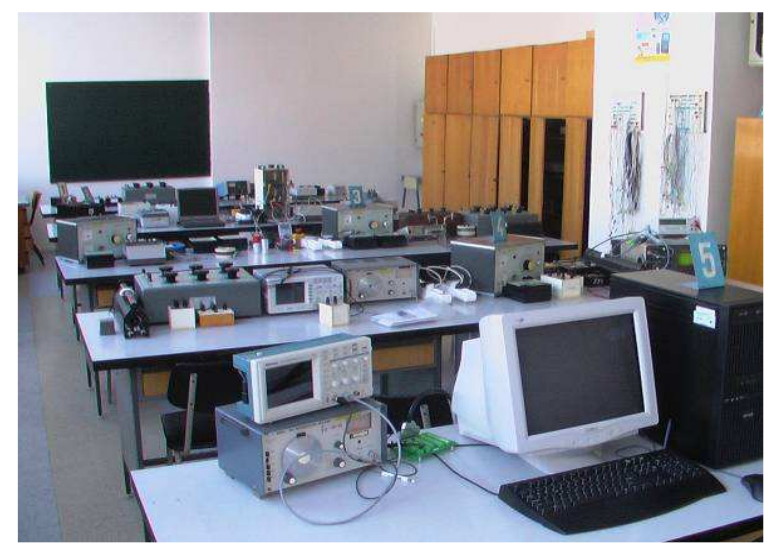

Fig. 3: Laboratory of measurement

For instance, it is necessary to switch on a simple generator in form of stand-alone device, set up a measured parameter and measuring range in order to perform measurement. The same measuring task can be done by means of computer equipped with needed hardware a software, simply by clicking the appropriate icon in graphical environment, for illustration see pictures (Fig.1 and 2) of VI generator created at our Department in Žilina (Fig.3) in LabVIEW program. So the computer acts as a measuring instrument even if in reality, it is not.

A complex virtual measuring system can originate in computer by means of implementation of numerous simultaneous or consequential measuring functions (Fig.4).

On the left hand side of Fig.4, there are two sources of measured parameters illustrated technological process and tested product. In both cases, bi-directional communication is utilized action parameters of regulation circuits, desired values of parameters, etc., represent input to technological process; simulation signals represent input to tested product. In opposite direction that means into the system there is a flow of measured parameters.

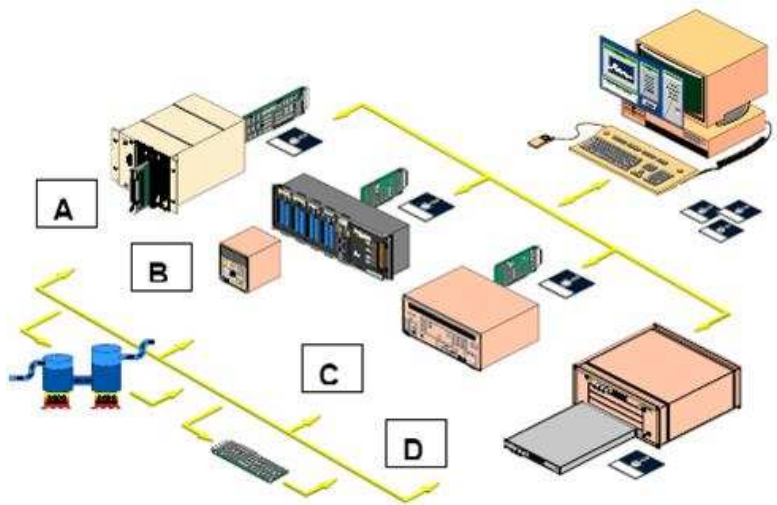

Fig. 4: Measuring chain of components for build-up of virtual measuring system

In the middle part of Fig.4, there is an illustration of standard option used in the phase of measurement data collection. In this part of system, the measured parameter is changed into electrical signal, transferred into digital form and unified according to interface used:

A - plug-in measuring card with a front-end module for modification of measured signal,

B - programmable logic computer (PLC) with communication interface,

$\mathrm{C}$ - measuring device with communication interface (GPIB, RS 232),

D - VXI measuring system.

On the right hand side of Fig.4, there is a computer with application which carries out function of virtual instrument. Increased 
performance parameters of today's computers enable to create very sophisticated systems, which maintain fundamental advantage for end user - high flexibility based on modification ability of software application which controls system behaviour in relation to changing needs of end user [6].

Main advantage of Virtual Instrument is effective implementation costs - the same computer carries out common tasks as well as measurements. Next advantage is flexibility, e.g. the same hardware can be used as voltmeter as well as thermometer, oscilloscope or spectral analyser, just simply by making small adaptation in the software. From the hardware point of view, appropriate circuits capable of communication with measured parameters need to be connected to PC. These are for instance analogue-to-digital or digital-to-analogue convectors with support circuits, often realized as Plug-in-Board, sometimes called Instrument on a Card.

Personal computer using its huge computing performance enables consequent analysis of acquired measuring data. It is very effective, simply using a method of numerical signal processing. Method selection as well as entire control of measuring process is easy to realize using standard controls of computer - keyboard, mouse, etc. Results of data processing can be presented in graphical format directly on the screen, can be printed out in form of measuring protocol or be saved on disk or diskette.

Computer in position of virtual measuring instrument enables to carry out extensive and long-term measurements without human presence. Collected data are stored on disk, diskette or are transported by telecommunication channel (telephone line, computer network LAN, WAN, Intranet, Internet, etc.) into control centre for further processing. Basic pre-processing such as data compression, peak detection, max and min signal, calculation of effective value, current performance, energy, different statistical parameters of signal, etc. can be done directly at the place of measuring.

In the middle part of Fig.4, there is an illustration of standard option used in the phase of measurement data collection. In this part of system, the measured parameter is changed into electrical signal, transferred into digital form and unified according to interface used:

A - plug-in measuring card with a front-end module for modification of measured signal,

B - programmable logic computer (PLC) with communication interface,
C - measuring device with communication interface (GPIB, RS 232),

D - VXI measuring system.

On the right hand side of Fig.4, there is a computer with application which carries out function of virtual instrument. Increased performance parameters of today's computers enable to create very sophisticated systems, which maintain fundamental advantage for end user - high flexibility based on modification ability of software application which controls system behaviour in relation to changing needs of end user [6].

Main advantage of Virtual Instrument is effective implementation costs - the same computer carries out common tasks as well as measurements. Next advantage is flexibility, e.g. the same hardware can be used as voltmeter as well as thermometer, oscilloscope or spectral analyser, just simply by making small adaptation in the software. From the hardware point of view, appropriate circuits capable of communication with measured parameters need to be connected to PC. These are for instance analogue-to-digital or digital-to-analogue convectors with support circuits, often realized as Plug-in-Board, sometimes called Instrument on a Card.

Personal computer using its huge computing performance enables consequent analysis of acquired measuring data. It is very effective, simply using a method of numerical signal processing. Method selection as well as entire control of measuring process is easy to realize using standard controls of computer - keyboard, mouse, etc. Results of data processing can be presented in graphical format directly on the screen, can be printed out in form of measuring protocol or be saved on disk or diskette.

Computer in position of virtual measuring instrument enables to carry out extensive and long-term measurements without human presence. Collected data are stored on disk, diskette or are transported by telecommunication channel (telephone line, computer network LAN, WAN, Intranet, Internet, etc.) into control centre for further processing.

Basic pre-processing such as data compression, peak detection, max and min signal, calculation of effective value, current performance, energy, different statistical parameters of signal, etc. can be done directly at the place of measuring. 


\section{Measuring set-up - NI ELVIS}

American company National Instruments developed an educational laboratory set-up NI ELVIS based on principle of LabVIEW. NI ELVIS system substitutes whole range of classic laboratory instruments and contains experimental means for design of electronic circuits.

\subsection{Hardware}

The system (Fig.5) consists of computer (1) with LabVIEW a multifunction card installed (2). Computer is connected to a work station (7) by 68-pin cable (3). Prototype board (4) is connected to a work station by connector (5). Inside of work station there are circuits for connection and protection of prototype board and motherboard. Power supply of a prototype board is switched on by the switch (6) on the front control panel of work station.

Hardware of NI ELVIS system works with multifunction card which must contain at least 16 analogue input channels with a sampling frequency of $200 \mathrm{kS} / \mathrm{s}, 2$ analogue output channels, 8 digital inputs/outputs and 2 counters/timers. Analogue inputs and outputs maintain input of measured signals into computer and output of adjusted parameters of devices.
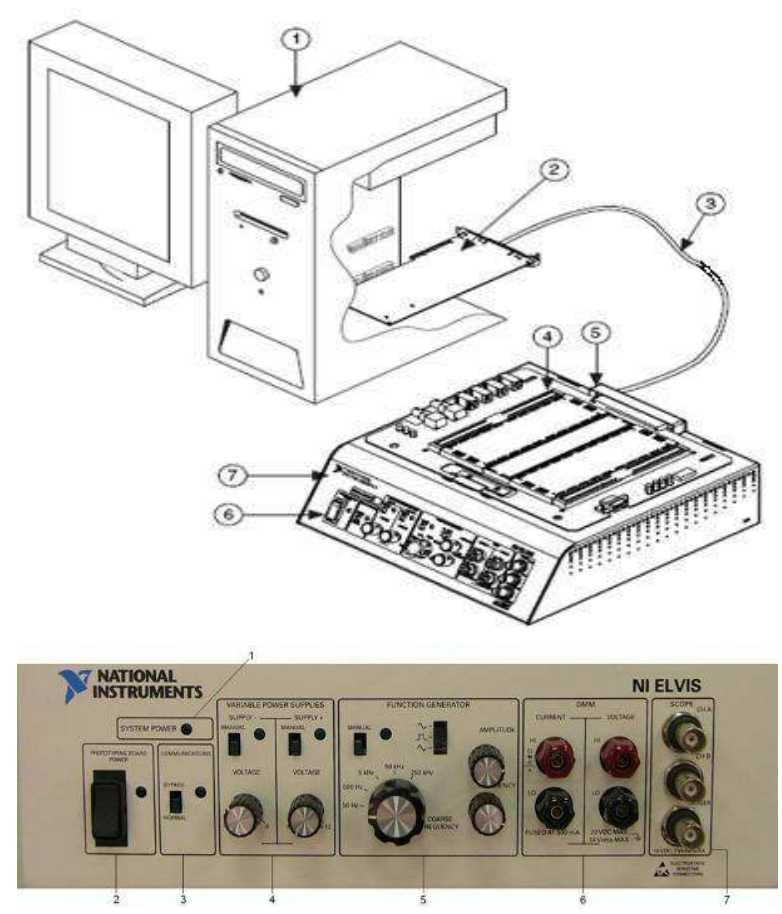

Fig.5 NI ELVIS system and its front control panel (1-power supply, 2-switch of power supply for prototype board, 3-communication switch, 4adjustable power supplies, 5-function generator, 6-inputs of digital multimeter, 7-inputs of oscilloscope).
Measured signal and circuits are connected either from outside through connectors of front control panel (Fig.5) or through contacts of interconnecting fields of prototype board. These inputs are connected in parallel and can not be used at the same time. Regulated voltage is as well directed to connectors of front control panel or to prototype board.

\subsection{Software}

NI ELVIS software is created in LabVIEW program. Software instruments are accessible through the window with Instrument Launcher (Fig.6). Generator of ARB sequence, frequency Bode Analyzer), Digital bus Reader, Digital bus Writer, Digital Multimeter (DMM), Dynamic Signal Analyzer (DSA), Function Generator (FGEN), Impedance Analyzer, Scope, Two-Wire and Three-Wire Current-Voltage Analyzers and Variable Power Supplies are available.

Digital multimeter can be used for numerous operations. By clicking on Ohm $[\Omega]$ icon it is used as digital ohmmeter, as digital multimeter it can be utilized for measuring of condenser capacity, coil and diode inductivity and as a voltmeter it measures direct and alternating voltage and as an ammeter it measures direct and alternating current [5].

Most of the circuits for alternating current and design of good circuits directly depends on instruments used for measuring the elements, on impedance and visual display of sequence on scope screen. Utilizing capable instruments and knowledge of electronic circuits, it is possible to fine-tune an electronic circuit so as to achieve its best response.

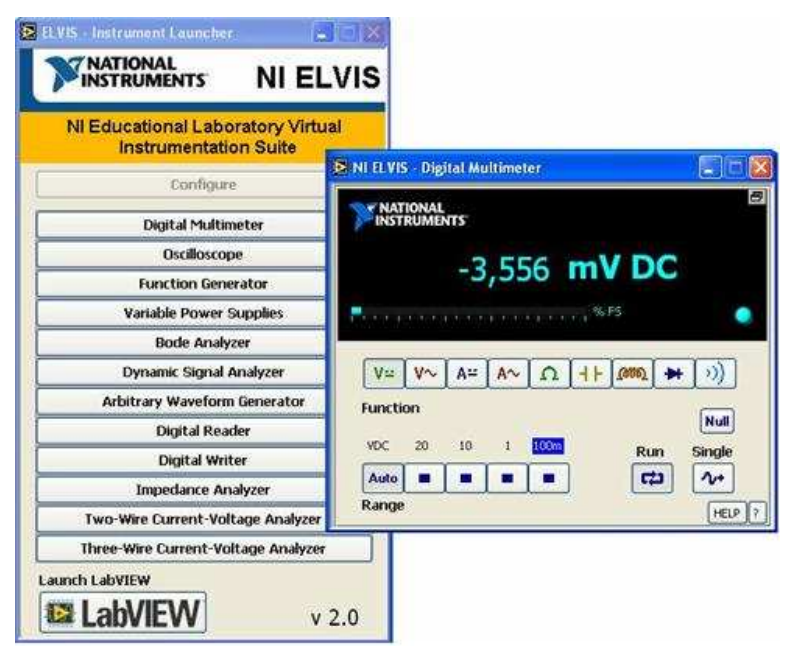

Fig. 6: NI ELVIS main panel a digital multimeter 
4. Example of measuring task carried out through internet using NI ELVIS

This chapter describes lab measuring task which is carried out by student over the internet using NI Elvis system.

\subsection{Registration}

In „Database registration“ (Fig.7) a student will choose appropriate year and student group and by clicking the „New Student“ icon the student enters his name and surname.

Confirming this dialogue window the student is registered in database table "Students“. Value of voltage and 3 frequencies are randomly generated and used for his/her measurement.

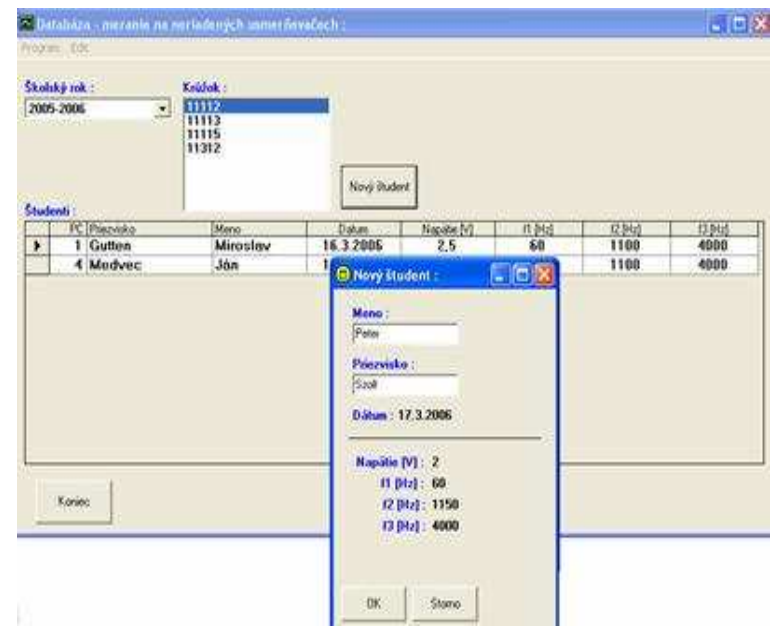

Fig. 7: Database for student registration

\subsection{Measurement on uncontrolled regulator}

In „NI ELVIS“ program created in LabVIEW, the student will set up values assigned by registration - voltage (Fig.8) and 3 frequencies step by step.

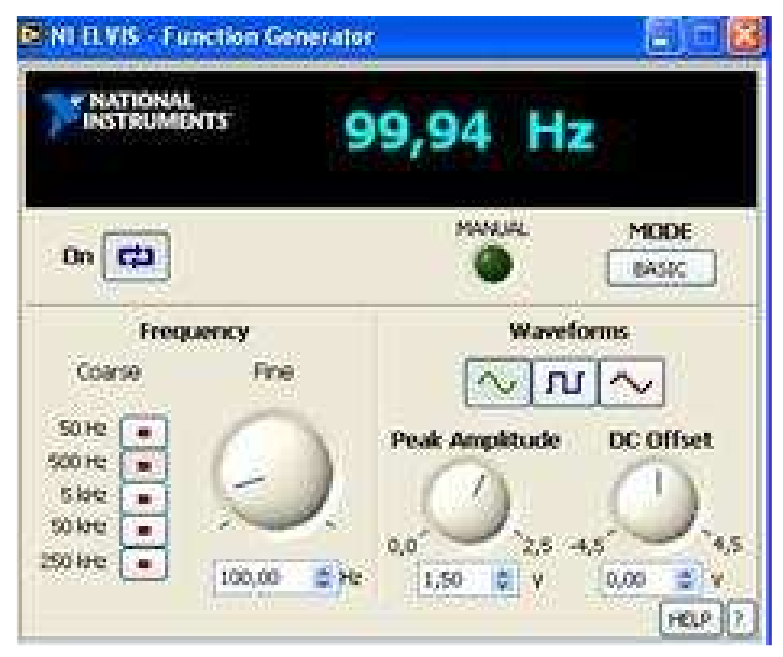

Fig. 8: Function generator

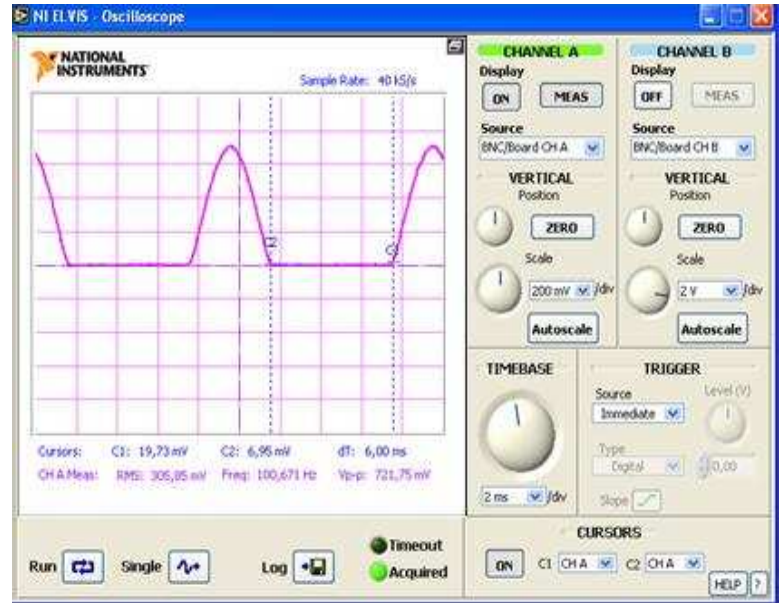

Fig. 9: Oscilloscope window with controls

By clicking on „Oscilloscope“ icon, a oscilloscope dialogue window opens.

Clicking the icons „On“ a „Meas“ will initiate display of rectified voltage of effective load on oscilloscope (Fig.9) as well as measured frequency values (Freq) and voltages in effective (RMS) a maximum value $\left(U_{\mathrm{P}-\mathrm{P}}\right)$.

Clicking the icon „On“" in „Cursors" field, students are enabled using a dash cursor $\mathrm{C} 1$ a $\mathrm{C} 2$ (Fig.9) to measure duration in ending direction for delay of junction diode in ending direction by higher frequencies.

\section{Conclusion}

VI systems applied in educational process can run over internet in form of measurement of defined parameters for electric and physical circuits. These new forms of measurements improve students' education and their preparation for practical measuring task.

At the same time there is no risk of accident comparing to standard lab conditions. Wearing of materials and components as well plays an important role because there is no mechanical stress applied, e.g. by repeated circuit build-up, and there is no chance to damage the elements by means of unprofessional handling. System set up can control that the created measuring tasks for a particular term do not change. Moreover, the system will not allow to exceed a set point during measurement.

\section{Literature}

(1) GUTTEN, M., KÚDELČÍK, J., BRANDT, M.: Možnosti laboratórnych meraní cez internet, Rozvoj schopností žiakov v prírodovednom vzdelávaní - Medzinárodná konferencia DIDFYZ 2006, Račkova dolina, Zborník 
príspevkov, Nitra 2007, ISBN 978-80-8094-0836

(2) GUTTEN, M., KÚDELČÍK, J., ŠIMKO, M.: Meracie prístroje a systémy elektrických a neelektrických veličín, Vysokoškolské skriptá, Žilinská univerzita v Žiline v Edis, Žilina 12/2006, 115 strán, ISBN 80-8070-619-0

(3) GUTTEN, M., ŠIMKO, M., KORENČIAK, D., BRANDT, M.: Elektrické meranie v experimentálnych úlohách, Vysokoškolské skriptá, Žilinská univerzita v Žiline v Edis, Žilina 12/2006, 79 strán, ISBN 80-8070-644-1

(4) KONDELOVÁ, A., IZÁK, P., BARČÍK, R.: Využitie NI ELVIS - LabVIEW v diagnostike Elektronických systémov, In: Nové smery $\mathrm{v}$ diagnostike a opravách elektrických strojov a zariadení: zborník prednášok IV. medzinárodnej vedeckej a odbornej konferencie, Malá Lučivná, 2006. S. 105-108. ISBN 80-8070-545-3.

(5) http://zone.ni.com/devzone/cda/tut/p/id/ 3711\#toc7

(6) ŽÍDEK, J.: Grafické programování ve vývojovém prostředí LabVIEW, Výuková skripta, Ostrava,ř́ijen 2002

(7) VOLKO, P.: Virtuálna inštrumentácia a meranie cez internet, bakalárska práca, Žilina, 2008 doc. Ing. Miroslav Gutten, PhD.

Žilinská univerzita

Elektrotechnická fakulta

Katedra merania a aplikovanej

elektrotechniky

Univerzitná 8215/1

01026 Žilina

Slovenská republika

e-mail:

gutten@fel.uniza.sk

\section{Ing. Daniel Korenčiak}

Žilinská univerzita

Elektrotechnická fakulta

Katedra merania a aplikovanej

elektrotechniky

Univerzitná 8215/1

01026 Žilina

Slovenská republika

e-mail:

korenc@fel.uniza.sk 